\title{
The Effect of Planting Media on Growth and Yield of Red Lettuce (Lactuca sativa L) in Aquaponic System
}

\author{
Ahmad Taofik $^{1}$, Budy Frasetya Taufiq Qurohman ${ }^{2}$, and Amalia Fitri Akhlasa ${ }^{3}$ \\ \{taofikuin@uinsgd.ac.id ${ }^{1}$ \} \\ Faculty of Science and Technology, UIN Sunan Gunung Djati Bandung ${ }^{1}$
}

\begin{abstract}
Aquaponics is a combination of aquaculture and hydroponics technology application to rearing fish and plants by utilizing recirculation systems. Waste produced by fish such as food and metabolic waste (feces and urine) can use as fertilizer for plantsthe water which contains food and metabolic waste furthermore flowing to planting media and plant absorption the nutrient so the water quality can reuse for fish culture. The objective of this study was to determine the effect of planting media on the growth and yield of red lettuce plants in aquaponics. Design experiment use nested completely randomized design. The data analysis using ANOVA, and the Duncan Multiple Range Test. The experiment consists of 3 treatments and nine replications. Media planting are rice husk charcoal, zeolite, and cocopeat. The results showed that the rice husk charcoal and zeolite substrate significantly affects number of leaves, fresh weight, and dry weight compared to cocopeat media. The red lettuce using zeolite as planting medium showed that higher growth of plant compared to plants with other types of substrate medium
\end{abstract}

Keywords: planting media, red lettuce, aquaponic

\section{Introduction}

Aquaponics is a combination of aquaculture and hydroponics technology application to rearing fish and plants by utilizing recirculation systems. Aquaponics combines re-circulatory aquaculture system with hydroponics system in an integrated symbiotic farming concept that ensures efficient nutrient recycling. In this system, the excretory products of the fish are broken down by microorganisms and the resultant by-products inputted into the hydroponic system for plant growth [1].

Waste produced by fish such as food and metabolic waste (feces and urine) can use as fertilizer for plants-the water which contains food and metabolic waste furthermore flowing to planting media and plant absorption the nutrient so the water quality can reuse for fish culture. Aquaponics is an alternative cultivation of plants and fish in one place, or in other words aquaponic is a combination of aquaculture and hydroponics that is able to recycle nutritious water by using a small portion of water for integrated growth of fish and plants. This system is almost the same as mina padi, namely fish and rice cultivation in a place [2]. Aquaponic able to producing up to three and six times the quantity of plants output of a conventional planting 
system [3] and utilise less amount of freshwater needed to produce fish in a conventional aquaculture system [4].

Today aquaponic developed to modern cultivation technique, medium for growing plants not only soil but using other materials which suitable for urban conditions that have limited yard [5]. Various planting media materials have been develop in previous study, to support plant growth and development.. In aquaponic cultivation the recirculation process reuses the water used in fish farming with filters in the form of plants and media.

Red lettuce, Lactuca sativa L plants are leafy, position of leaves sorround the stem. Leaves have a variety of shapes and color [6]. Red lettuce is a vegetable plant with an aesthetic, wavy and red leaf shape. Aquaponic planting media can using both of organic and inorganic media. Husk and cocopeat charcoal are organic planting media, while zeolite is an inorganic. The objective of this study was to determine the effect of planting media on the growth and yield of red lettuce plants in aquaponics.

\section{Research Purpose}

This research purpose are to develop the media planting for aquaponic and reference to further study in aquaponic system.

\section{Method}

The experimental design used in this study was a completely randomized design consists of 3 treatments type of planting media, Husk Charcoal, Zeolite and Cocopeat, with 9 replications nested in treatments. The variable measure are plants height $(\mathrm{cm})$, leaf number, leaf area $\left(\mathrm{cm}^{2}\right)$ and fresh weight of plant $(\mathrm{g})$. Plants height $(\mathrm{cm})$. Plant height is measured using a measuring tape from the surface of the media to the point of growing plants. Measurements are carried out once a week, 7, 14, 21, 28 and 35 days after planting (DAP). Leaf number. The number of leaves is calculated by counting the number of leaves of the plant. The number of leaves counted is leaves that have grown perfectly, bloomed, not yellowed and leaves that grow normally. The measurement time same to the plant height measurement. Leaf area $\left(\mathrm{cm}^{2}\right)$. Measuring leaf area is done after the crop is harvested at 35 DAP. The method used is the Gravimetric Method. Fresh weight of plant $(\mathrm{g})$. Measurements done by weighing the faint parts of the plant, at 35 DAP. Collected data, were analize by analysis of variance, since ANOVA significant effect, followed by Duncan multiple test range (DMRT).

\section{Result and Discussion}

\subsection{Supporting Observations}


There are $\mathrm{pH}$ and Electric Conductivity (EC) value, tempertature and humidity, disolve oxgen, amonia level, also weight of fish. The range of $\mathrm{pH}$ values in pond with husk charcoal media (pond A) 7.5 - 7.8, pond with zeolite media (pond B) 7.13 - 8.1, and pond with cocopeat media (pond C) $7.04-7.7$. At the harvest time (35 DAP) the $\mathrm{pH}$ value decreases compare to first time. Increase of $\mathrm{H}^{+}$concentration occurs due to degradation of water quality caused by residual feed, feces, algal respiration, and reduced $\mathrm{CO} 2$ in water [7].

The average $\mathrm{EC}$ value in pond $\mathrm{A}$ is $0.29 \mathrm{mS} \mathrm{cm}^{-1}$, pond $\mathrm{B}$ is $0.25 \mathrm{mS} \mathrm{cm}^{-1}$, and pond $\mathrm{C}$ is $0.28 \mathrm{mS} \mathrm{cm} \mathrm{cm}^{-1}$ and temperature range $23^{\circ} \mathrm{C}-27^{\circ} \mathrm{C}$. Electrical conductivity in water is caused by organic decomposition and temperature. Temperature and electrical conductivity is a linear relationship [8]. Increase of the temperature, causing increase the ions move faster and the value of the electrical conductivity will also increase. Electrical conductivity value in nutrient solutions affect plant metabolism, photosynthesis, enzyme activity, and the potential absorption of solution ions by roots [9].

Maximum daily temperature reaches $30^{\circ} \mathrm{C}$, the minimum $19^{\circ} \mathrm{C}$, daily average temperature $26^{\circ} \mathrm{C}$. Optimal temperatures for red lettuce is $15-20^{\circ} \mathrm{C}$, other range temperatures causing the growth of red lettuce un-optimal [10].

The average of dissolved oxygen in pond $\mathrm{A}$ was $9.18 \mathrm{mg} \mathrm{L}^{-1}$, in pond $\mathrm{B}$ it was $9.45 \mathrm{mg} \mathrm{L}^{-1}$ while in pond $\mathrm{C}$ it was $10.13 \mathrm{mg} \mathrm{L}^{-1}$. Dissolved oxygen in each pond was classified as high. In this study using recirculation aquaculture system, the water always flowed. The faster flow water in the drainage chamber, the oxygen diffuses water better. The minimum of dissolved oxygen for fish is around $5.0 \mathrm{mg} \mathrm{L}^{-1}$, for plant roots around $2.5 \mathrm{mg} \mathrm{L}^{-1}$, and for bacteria around $2.0 \mathrm{mg} \mathrm{L}^{-1}$ [11].

The average ammonia level in pond $\mathrm{A} 0.003 \mathrm{mg} \mathrm{L}^{-1}$, pond $\mathrm{B} 0.001 \mathrm{mg} \mathrm{L}^{-1}$ and pond $\mathrm{C}$ is $0.01 \mathrm{mg} \mathrm{L}^{-1}$. Ammonia levels in all media are low and harmless. Ammonia from waste of the metabolism of fish (feces and urine) has recycle by bacteria into nitrites and nitrates so can be utilized by plants as a source of nitrogenous nutrients. The lowest ammonia level is in zeolite planting media. Zeolite able to absorb ammonia with its rough surface and as a medium attached to microorganisms (bio-films) which can utilize various elements that are suspended in water and absorbed with microorganisms' food ingredients [12]. In each pond, 50 fish were filled, nirvana tilapia (Oreochromis niloticus) body length 5-7 cm, average weight 10 grams, rear for 49 days. Average body gain in pond A $11.35 \mathrm{~g}$, pond B $11.58 \mathrm{~g}$ and pond C $8.74 \mathrm{~g}$, better then reported by Mulqan et al., [13].

\subsection{Plant Height}

The effect of planting media on plant height, showed in Table 1.

Table 1. Effect of planting media on red lettuce plant height 


\begin{tabular}{crrrrrrrrrrr}
\hline \multirow{2}{*}{ Planting Media } & \multicolumn{10}{c}{ Plant Height (cm) } \\
& 7 DAP & 14 DAP & 21 DAP & 28 DAP & 35 DAP \\
A & 8.28 & a & 11.11 & a & 14.04 & a & 17,00 & a & 21.09 & a \\
B & 9.00 & a & 10.86 & a & 14.19 & a & 16.11 & a & 19.20 & a \\
C & 9.00 & a & 10.77 & a & 13.68 & a & 16.87 & a & 20.45 & a \\
\hline
\end{tabular}

Planting media has no significant effect on plant height. Fariudin et al., [14] reported that in aquaponic cultivation without planting media the average of lettuce height only $6.24 \mathrm{~cm}$. In this study showed that the use of planting media can optimize plant growth in aquaponic cultivation. 


\subsection{Leaf Number}

Table 2 showing the effect of planting media on leaf numbers.

Table 2. Effect of planting media on red lettuce leaf number

\begin{tabular}{ccccccccccccc}
\hline \multirow{2}{*}{ Planting Media } & \multicolumn{10}{c}{ Leaf Number } \\
& 7 DAP & & 14 DAP & 21 DAP & & 28 DAP & & 35 DAP \\
A & 3.44 & a & 5.22 & a & 6.33 & a & 7.56 & a & 9.44 & b \\
B & 3.44 & a & 5.33 & a & 6.44 & a & 7.33 & a & 9.55 & b \\
C & 3.56 & a & 5.11 & a & 6.44 & a & 7.56 & a & 7.00 & a \\
\hline
\end{tabular}

According to Table 2, leaf number red lettuce until 28 DAP no significant affect of planting media. Nitrogen is part of protoplasm, enzymes, and as a biological catalyst agents, therefore $\mathrm{N}$ is a very important element for plant growth to accelerate the life process [15]. The number of leaves in this study better then Fariudin et al. [14], but the lower then Zuhaida [16]. Cocopeat planting media (C) shows the lowest results, the ability of cocopeat to bind and store water is very strong. It is causes gas exchange in the media to experience obstacles so that the roots experience resistance in breathing and nutrient absorption is not optimal [8].

\subsection{Leaf Area $\left(\mathrm{cm}^{2}\right)$}

Leaf area measure after the crop harvested at 35 DAP. Effect of media planting on leaf area displayed on Table 3.

Table 3. Effect of planting media on red lettuce leaf area

\begin{tabular}{ccc}
\hline Planting Media & Leaf Area $\left(\mathrm{cm}^{2}\right)$ & \\
A & 400.15 & a \\
B & 611.59 & a \\
C & 287.11 & a \\
\hline
\end{tabular}

The lowest leaf area in this study is on the cocopeat media planting, compare to zeolite media and husk charcoal. Zeolite able to high nutrient absorption capacity, especially $\mathrm{K}$ and $\mathrm{NH}_{4}$, zeolite is also able to increase nitrogen efficiency, especially reducing nitrate washing. Based 
on the high exchange ability of cations, zeolite able to bind and store water and fertilizer temporarily and easily release to plants when needed (as slow release fertilizer) [17].

\subsection{Fresh Yield of Plant}

Fresh weight is weighed at 35 DAP. Media planting effect on fresh yield of plant showed on Table 4. 
Table 4. Effect of planting media on red lettuce fresh yield weight

\begin{tabular}{ccc}
\hline Planting Media & Fresh Yield (g) & \\
\hline A & 30.5 & b \\
B & 49.88 & b \\
C & 24.63 & a \\
\hline
\end{tabular}

Planting media significantly affect to red lettuce fresh yield weight. Between the husk charcoal media (A) and zeolite (B) showed that the average yield was not significantly different but compare to cocopeat media $(\mathrm{C})$ was significantly different.

Hollow zeolite structure can be filled by water and cations, so that it can be useful as an absorbent of nutrients derived from the waste of the feed and fish metabolism. The use of zeolite can increase the growth of plant because the content of ammonia, phosphorus and potassium in water is low, so that the water used by plants is of higher quality [18]. Anjani and Kusdarwati [19] reported that zeolite able to reduce ammonia. The rough and hollow zeolite surface can be precisely attached to microorganisms that helpful in the oxidation process of organic matter.

Lettuce plants grown with a hydroponic system produced $126.94 \mathrm{~g}$ of fresh weight [15]. The range of EC values in this study is $0.25-0.3 \mathrm{mS} \mathrm{cm}^{-1}$ while the $\mathrm{pH}$ value is $7.04-8.1$. The range of EC values and $\mathrm{pH}$ recommended by Rakocy et al. [20] is $0.3-0.6 \mathrm{mS} \mathrm{cm}^{-1}$ and $\mathrm{pH} 6.5$ -7.5 .

\section{Conclusion}

Planting media have significant effect to leaf number and fresh yield of red lettuce. Zeolite tend to better media than husk charcoal and cocopeat.

\section{Reference}

[1]. Bosma, R.H., Lacambra, L., Landstra, Y., Perini, C., Poulie, J., Schwaner, M.J., Yin, Y., 2017. The financial feasibility of producing fish and vegetables through aquaponics. Aquacult. Eng. 78, 146154.

[2]. Fathulloh, A. S. dan Budiana, N. S., 2015. Akuaponik Panen Sayur Bonus Ikan. Jakarta: Penebar Swadaya

[3[. Resh, H.M., 2004. Hydroponic Food Production: A Definitive Guide for the Advanced Home Gardener and Commercial Hydroponic Grower. New Concept Press, Inc., Mahwah, New Jersey, USA. 
[4]. Liang, J.Y., Chien, Y.H., 2015. Effects of photosynthetic photon flux density and photoperiod on water quality and crop production in a loach (Misgurnus anguillicandatus) enest fern (Asplenium nidus) raft aquaponics system. Int. Biodeter. Biodegr 102, 214-222. (Liang and Chien, 2015)

[5]. Rafiee, G., dan Che Roos Saad. 2006. The Effect of Natural Zeolite (Clinoptiolite) on Aquaponic Production of Red Tilapia (Oreochromis sp.) and Lettuce (Lactuca sativa var. longifolia), and Improvement of Water Quality. Journal Agric. Sci. Technol. Vol. 8: 313-322

[6]. Sumarni. 2001. Budidaya Selada Merah Intensif. Yogyakarta: Kansius

[7]. Zidni, Irfan., Herawati, Titin., dan Liviawaty, Eva. 2013. Pengaruh Padat Tebar terhadap Pengaruh Benih Lele Sangkuriang (Clarlas garlepinus) dalam Sistem Akuaponik. Jurnal perikanan dan kelautan Vol. 4 No. 4, Desember 2013: 315-324.

[8]. Irawan, Fadhilah., dan Afdal. 2016. Analisis Hubungan Konduktivitas Listrik dengan Total Dissolve Solid (TDS) dan Temperatur pada Beberapa Jenis Air. Jurnal Fisika Unand Vol. 5, No. 1.

[9]. Suryani, Rani. 2015. Hidroponik budidaya tanaman tanpa tanah. Arcitra. Yogyakarta

[10]. Cahyono. 2003. Budidaya Tanaman Selada Merah. Bogor: Institut Pertanian Bogor.

[11]. Farida, N. F., \& Abdullah, S.H. 2017. Analisis Kualitas Air Pada Sistem Pengairan Akuaponik. Jurnal Ilmiah Rekayasa Pertanian Dan Biosistem, 5(2), 385-394

[12]. Nurhidayat. 2012. Efektivitas Kinerja Media Biofilter Dalam Sistem Resirkulasi Terhadap Kualitas Air, Pertumbuhan dan Sintasan Ikan Red Rainbow (Glosso-lepis inasus weber). J. Ris. Akuakultur Vol. 7 No. 2 : 279-292

[13]. Mulqan, Muhamad. Sayyid AR. Irma D. 2017. Pertumbuhan dan Kelangsungan Hidup Benih Ikan Nila Gesit (Oreochromis niloticus) pada Sistem Akuaponik dengan Jenis Tanaman yang Berbeda. Jurnal Ilmiah Mahasiswa Kelautan dan Perikanan Unsyiah Volume 2, Nomor 1: 183-193

[14]. Fariudin, R., \& Sulistyaningsih, E. 2013. Pertumbuhan Dan Hasil Dua Kultivar Selada (Lactuca sativa, L.) Dalam Akuaponika Pada Kolam Gurami Dan Kolam Nila. Jurnal Vegetalika, 2(1), 66-81.

[15]. Nugroho, Ristiawan Agung \& Pambudi. 2012. Aplikasi Teknolgi Aquaponic pada Budidaya Ikan Air Tawar untuk Optimalisasi Kapasitas Produksi. Jurnal Saintek Perikanan. Vol. 8. No.1.

[16]. Zuhaida, L., Ambarwati, E. Dan Sulistya ningsih, E. 2012. Pertumbuhan dan Hasil Selada (Lactuca SativaL.) Hidroponik Diperkaya Fe. Jurnal Vegetalika. 1 (4) : 132-146.

[17]. Suwardi. 2009. Teknik Aplikasi Zeolit Di Bidang Pertanian Sebagai Bahan Pembenah Tanah. Jurnal Zeolit Indonesia. Vol 8 No 1.

[18]. Rafiee, G., dan Che Roos Saad. 2006. The Effect of Natural Zeolite (Clinoptiolite) on Aquaponic Production of Red Tilapia (Oreochromis sp.) and Lettuce (Lactuca sativa var. longifolia), and Improvement of Water Quality. Journal Agric. Sci. Technol. Vol. 8: 313-322

[19]. Anjani, P. T., \& Kusdarwati, R. (2017). Pengaruh Teknologi Akuaponik dengan Media Tanam Selada (Lactuca sativa) terhadap Pertumbuhan Belut (Monopterus albus). Journal of Aquaculture and Fish Health, 6(2), 67-73. 
[20]. Rakocy J, Nelson RL, dan Wilson G. 2005. Aquaponic is the combination of aquaculture (fish farming) and hydroponic (growing plants without soil). In:Question and answer by Dr. James Rakocy. Aquaponics Journal. 4 (1): 8-11. 